\title{
Pawel Lont
}

University of Lodz

e-mail: pawel.lont@unilodz.eu

ORCID: 0000-0002-1084-0762

\section{COMPETITION ON THE LNG MARKET - CONSEQUENCES FOR THE EU}

\author{
DOI: $10.15611 / \mathrm{pn} .2020 .6 .10$ \\ JEL Classification: Q02, F18, D47, L99
}

\section{(C) 2020 Paweł Lont}

This is an open access article distributed under the Creative Commons Attribution-NonCommercial-NoDerivs license (http://creativecommons.org/licenses/by-nc-nd/3.0/)

Quote as: Lont, P. (2020). Competition on the LNG market - consequences for the EU. Prace Naukowe Uniwersytetu Ekonomicznego we Wrocławiu, 64(6).

\begin{abstract}
The aim of this article is to assess the impact of the natural gas sector's gradual transition towards a globally-traded commodity market for EU economies. The literature review provides evidence of regulatory, technological and business practice changes that have led to the development of a global gas market. A statistical analysis of the price spreads between the regions and of the differences in the LNG shipment costs is performed to verify whether competition over cargoes at a global level observed over the last years is not temporary. The results confirm that the market-based price indices have become a more relevant and popular form of price reference for short and long-term LNG supply contracts than oil indexation. The author concludes that the transition from regional markets to a global market has brought multiple benefits to EU economies that can be largely lost if Asian economies will be ready to pay substantial premiums for LNG cargoes in the future.
\end{abstract}

Keywords: LNG, competition, oil index, gas hub.

\section{Introduction}

The liberalization of the gas markets is a process with a long history in the USA and the European Union, the aim of which was to ensure competition that would minimize the costs of natural gas to the consumers. The transition towards market-based competition developed well in these regions, signalling that trading activities and the freedom to choose a supplier can positively affect the prices paid by end-customers, therefore improving the competitive position of the economy. These developments, in combination with technological shifts towards cheaper and efficient gas appliances have gradually decoupled oil and natural gas prices, making the once standard oil indexation for gas trade agreements obsolete. Spot and forward price indices from 
the most liquid hubs, particularly in the Netherlands and the USA, have started to provide an important reference to a growing number of transactions worldwide.

The high prices stemming from oil indexation under long-term contracts have encouraged multiple investments in liquified natural gas (LNG) infrastructure, both by the suppliers and the importing countries. The market for LNG cargoes that was primarily concentrated in Asia and partially in Spain and USA, has developed to a stage where the ship-transported commodity could compete against pipeline deliveries. Energy trading companies have started to use cargoes to optimize their portfolios, and arbitrage between different regions, bringing about greater price convergence and transforming the sector from national or regional markets to a global, highly interconnected one.

The aim of this article is to analyse and assess the impact of the natural gas sector's gradual transition towards a globally-traded commodity market for European Union economies. The literature review provides evidence of the regulatory, technological and business practice changes that have led to the development of a global gas market. A statistical analysis of the price spreads between the gas importing countries and the differences in the LNG shipment costs was used to verify whether competition over cargoes at a global level observed over recent years is not a temporary state stemming from the existence of legacy contracts in some regions or a general commodity oversupply worldwide.

The article is divided into six parts. The first section provides a brief overview of the development of the gas sector in different parts of the world. Section 2 explains the process of the abandonment of oil-indexed long-term arrangements that have been the industry standard for many years. Section 3 outlines the research material and the research methodology used. Section 4 quantifies the changes in the LNG trading environment resulting from the shift towards market-based natural gas price discovery, backed up by statistical analysis of the prices and costs of the commodity at a global level. That section is followed by a discussion on the consequences of the globalization of gas trading for Europe. Finally, the conclusions are presented, summarizing the study results and underlining the main findings.

\section{Gas sector development in different parts of the world}

The development of the natural gas sector was typically managed through state-owned, vertically integrated companies, who were responsible for the construction, operation and maintenance of the infrastructure, as well as contacts with the consumers. The same approach in this respect could be observed in many countries around the world, especially since natural gas was seen as a model example of a public good offered by a 'natural' monopoly. As indicated by Posner (1968, p. 548), this naturalness stems from the supply method, where pipelines for different pressure levels are developed to deliver the commodity from the producers to the end-users. Since the development of such gas transportation grids is expensive and faces 
opposition from society related to the use of land, the establishment of competing, parallel routes would neither be logical nor possible.

Natural gas in Asia for a long time was not an important energy resource consumed, particularly because of the great geographical dispersion that made its transport particularly expensive. The large distance between the gas-rich Southeast Asia-Pacific region and the industrialized and developed Northeast has largely determined the focus of this market on liquified natural gas (LNG) shipping, as opposed to the pipeline gas transportation popular in the USA and Europe (Herberg, 2011, pp. 4-5). This difference has also largely contributed to the relatively high gas prices for consumers. Nonetheless, as different studies suggest, the demand for natural gas in Asia has multiplied over the past two decades and is expected to grow in the coming years (Chong, 2019, p. 4).

The United States is a country that considered the benefits of the liberalization of the gas market very early on. The strict regulation of all activities related to natural gas that constrained the price volatility already at production sites has led to supply shortages signalling the need to liberalize the prices so that they reflect the actual value of the commodity. The process of liberalization at the wholesale level started already in 1978, leading to the unbundling of gas transportation-related activities from trading and supply in 1992 (Juris, 1998, pp. 2-5). Regional markets swiftly grew in liquidity, particularly in the short-term, with one physical gas trading hub (Henry Hub) becoming the largest in the country, providing an important reference price for different transactions, including financial contracts over the long-term. Another milestone in the development of the US gas market was the transition from being an importer of natural gas to becoming a major exporter of LNG through a breakthrough in fracking technologies (Nalley, 2019, pp. 2-6).

In Europe, as the gas transmission infrastructure developed, discussions in the United Kingdom started in order to explore whether a state monopoly ensures cost efficiency and low prices to the consumers. This led to the decision to transform the sector in a way that would break up vertically integrated companies into a monopolistic part related to gas transmission and competitive activities related to gas supply and trading in the 1990s (Thomas, 2003, pp. 181-183). A similar approach was agreed in 1998 at EU level, through the adoption of the first Gas Directive (Directive 98/30/ EC). The founding principle in both cases was to ensure non-discriminatory access to gas transmission services in order to allow competition over end-customers, who were given freedom to choose their supplier (Price and Bennett, 1999, p. 2). Further development of truly market-based competition required a number of reinforcements implemented through recast Gas Directives that followed over the years. The prevailing problems in this context in different parts of Europe were:

- long-term contractual arrangements for gas supplies that retained reliance on a single gas supplier;

- long-term transmission capacity contracts that limited access to different gas markets by competing companies. 
Long-term contractual arrangements were a common practice at the time of national monopolies, yet they could no longer be retained if an internal market for natural gas in Europe was to be established. Therefore the developing and streamline legislation for natural gas in the EU has made many of the foreclosing features of long-term contracts (discussed in the next section) non-compliant. Consequently, as the long-term arrangements expired or have been revised and new connections between the Member State's grids developed, European markets for gas started to grow in liquidity. Countries in Central and Western Europe reached a relatively high level of liquidity, providing reliable price signals on both the spot and forward markets. This reliability has also fostered another important shift in the industry, where the price of gas was no longer referenced against oil prices, but became linked to the indices of the most reliable hubs in Europe, particularly in the Netherlands and the United Kingdom (see Table 1 below). The information in Table 1 shows a gas hub score assigned annually on a scale 1 to 20 by the European Federation of Energy Traders (EFET). The score evaluates both the general regulatory hub design features (such as balancing, information transparency) and its performance (including liquidity and activity of brokers and price reporting agencies). Eastern and South-Eastern countries of the EU were still struggling to develop liquid and reliable markets in 2019, which resulted from a combination of factors, including some long-term contracts in place and protective regulatory measures that discouraged competition from foreign companies. Particularly little progress can be seen in Bulgaria, Romania, Poland and Hungary.

Table 1. European gas hubs: development stages

\begin{tabular}{|l|l|l|l|l|l|l|}
\hline \multicolumn{1}{|c|}{ Hub name } & 2014 & 2015 & 2016 & 2017 & 2018 & 2019 \\
\hline NBP (UK) & 20 & 20 & 20 & 20 & 20 & 20 \\
\hline TTF (NL) & 19 & 19.5 & 19.5 & 19 & 19 & 19 \\
\hline NCG (DE) & 15.5 & 19 & 19 & 17.5 & 17.5 & 17.5 \\
\hline GASPOOL (DE) & 16 & 19 & 19 & 17 & 17 & 17.5 \\
\hline ZTP (BE) & 16 & 17.5 & 18 & 19 & 17 & 17.5 \\
\hline PSV (IT) & 10.5 & 15 & 15 & 16 & 16.5 & 17.5 \\
\hline TRF (FR) & 16 & 16.5 & 18.5 & 17.5 & 17 & 17 \\
\hline VTP (AT) & 13 & 13 & 13.5 & 16 & 16.5 & 17 \\
\hline PVB (ES) & 7 & 7 & 13.5 & 16 & 15.5 & 16 \\
\hline MGP (HU) & 5 & 6.5 & 9 & 12.5 & 11.5 & 12.5 \\
\hline Slovakia & 3.5 & 7 & 8 & 8.5 & 9.5 & 10 \\
\hline Poland & 4.5 & 5.5 & 9.5 & 10 & 9.5 & 9.5 \\
\hline Bulgaria & 1.5 & 1 & 1.5 & 1 & 4.5 & 5 \\
\hline Romania & 2.5 & 1.5 & 2 & 3 & 3 & 4.5 \\
\hline
\end{tabular}

Source: own work based on (European Federation of Energy Traders, 2019). 


\section{Changing business environment}

The abandonment of oil indexation in contracts between the producers, suppliers and traders initiated a new age in gas trading, where the commodity price started to reflect the actual supply and demand equilibrium for natural gas. Traditionally, the link between oil and gas prices stemmed from the fact that end-users actually chose between utilizing one of the two commodities depending on the price signals (Stern and Rogers, 2011, pp. 2-3). Through the development of gas-related technologies and its variations, and the availability of oil, the link has long lost its rationale, while retaining an inflexible arrangement between the producers and importers (Hulshof, van der Maat, and Mulder, 2016, pp. 480-484). While over the past decade, proponents of retaining the link to oil could still be found, particularly because the liquidity of the gas markets was imperfect and therefore perceived as an unreliable reference in the longer term, the situation has changed over recent years. As argued by Stern and Rogers (2011, pp. 5-12), liquid spot prices at the most developed European hubs were already well-founded and significantly lower than the oil-indexed deliveries back in 2011. It should be noted, though, that the 2019 report from the EU's Agency for Cooperation of Energy Regulators (ACER, 2019, p. 39) highlighted the fact that apart from the Dutch and British gas hubs, no reliable forward price reference was available at other European markets.

The traditional setup of long-term gas delivery contracts had a very detailed structure and enabled little flexibility in terms of volume of deliveries and the settlement price. The contract price was typically derived from oil indices with a sixmonth delay. In particular, as indicated by Melling (2010, pp. 127-135) specific contractual provisions included:

- take-or-pay clauses - where the producer is obliged to deliver and the buyer has the obligation to pay regardless of whether the delivery is accepted or not. The obligation is referenced against the annual contracted quantities and is set at e.g. $90 \%$ of the contracted amounts (or more for LNG shipments);

- destination clauses - provisions preventing reselling the contracted gas, or requiring the supplier's consent, possibly subject to further profit-sharing arrangements;

- events allowing for price renegotiation:

- changes in taxation related to indexed commodities,

- changes in legislation,

- major shifts in market value and hardship clauses - where a side of the contract experiences adverse changes to the market conditions that affect their economic position.

Destination clauses could be seen as one of the largest barriers to market development. The uneven market power of the companies contracting the gas with the sellers resulted in major differences in prices of gas offered to consumers even 
along the same supply route (Neumann and von Hirschausen, 2004, pp. 175-182). These clauses were heavily criticized for preventing market development and giving the sellers extraordinary power over the buyers.

Destination clauses used to be typical for LNG deliveries as well, which was particularly damaging to the flexibility of the trading companies as they needed to factor in the time necessary to deliver the commodity to a terminal (Shi and Variam, 2016, pp. 587-596). The review process could be triggered only once every couple of years, further exposing buyers to the risk of major deviations from the hub price. For these reasons, destination clauses have been targeted by the European Commission as non-compliant with EU competition law, leading to a series of cancellations of such clauses preventing diversions of gas deliveries inside the EU from existing and future contracts with most major suppliers into Europe. Similarly, an investigation held in Japan also found such clauses non-compliant in contracts that move the ownership of gas and associated shipment risks onto the buyer at the terminal (Free-On-Board, or FOB contracts) (Talus, 2018, pp. 2-3). In contrast, both the EU and Japan allow for destination clauses in Delivery-At-Terminal (DAT) contracts, where gas ownership and the associated risks are transferred onto the buyer at the offtake terminal, which seems only logical given that the responsibility for the cargo rests with the seller (Scherer, 2018).

Along with the expiry and/or modification of long-term supply contracts, opportunities have opened up for producers around the world to compete over the demand from gas importing countries, particularly in Europe (notably Spain) and Asia (notably Japan). New opportunities have induced investment in infrastructure allowing the liquefaction of the gas produced and its shipment over long distances. With a number of countries joining the competition in this area (particularly the US after the fracking revolution), the market has evolved from a producer's market to a consumer's market, where importers could push for more flexible arrangements (Janusz, Kaliski, and Szurlej, 2015, pp. 5-24).

\section{Research material and method}

The gradual transition of natural gas into a truly globally traded commodity provides a good opportunity to analyse the interactions between the previously regional markets of the world. In order to do that, the literature review was performed in order to identify the factors impacting competition over LNG cargoes between different regions. The factors affecting the actual transport costs and the most relevant price indices were also identified in the literature on the subject.

In order to analyse the actual interactions and ties between the most important markets of the world, namely Europe (particularly Spain), the USA, Japan and China, price statistics were collected from Thomson Reuters Eikon database. Statistical analysis of the delivery costs from the main producer to consumer markets were also analysed in this context in order to identify the actual spread level between different 
market that could effectively facilitate competition. Ultimately the analysis aims to prove that the global character of the natural gas market is not of a temporary nature. The research results are presented below.

\section{LNG trading going global}

With an ample supply of gas and multiple tankers distributing LNG to different parts of the world, particularly in 2018, this market has also moved to the short-term (see Figure 1 below), where traders conclude deals with the sellers and between each other directly to quickly monetize on the short-term spreads (Hartley, 2015, pp. 1-4).

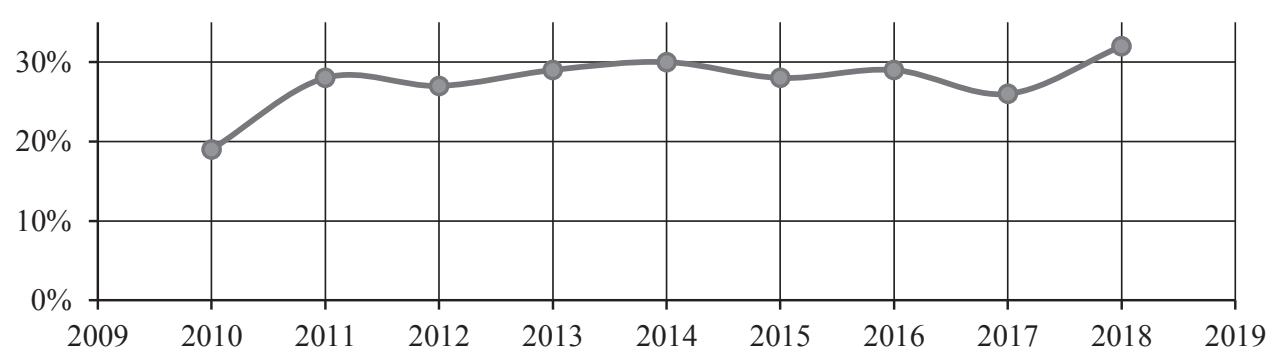

Fig. 1. Share of spot \& short-term LNG trades in total LNG transactions

Source: (International Group of Liquefied Natural Gas Importers, 2019a).

The shift in the market setup has encouraged other countries outside the EU and the USA (having liquid gas trading hubs) to seek price-discovery mechanisms appropriate for their region (Energy Information Administration, 2017, pp. 1-6). This seemed particularly desirable when considering that $76 \%$ of the entire LNG demand in 2018 actually came from Asia (International Group of Liquefied Natural Gas Importers, 2019b, p. 3). This opportunity was spotted particularly by Singapore, China and Japan, who started working on the establishment of a trading hub for LNG in the region. Yet, as was rightfully noted by the U.S. Energy Information Administration's (EIA), the establishment of liquidity is a time-consuming process, especially since it requires implementing a set of liberalizing measures that allow for the development of market-based competition, in particular the unrestricted access to infrastructure and the right to choose a supplier freely (Energy Information Administration, 2017, pp. 9-12). Xunpeng (2017, p. 3-5) highlights that the main obstacle in this context is the power of the incumbents in these countries that needs to be restricted to leave room for market-based competition. Considering the existing hurdles, it seems likely that the most reliable price indices for the region in the medium-term will be those offered by price reporting agencies that derive them from voluntary reported transactions from the region. 
What transpires from the knowledge of the oil-indexed prices being reported in Asia (notably through Japan's Crude Cocktail (JCC) index) is that under the existing market setup, Asian economies would pay twice as much for their LNG supplies than e.g. the USA or Europe (see Figure 3 below). Zhang, Shi and Shi (2018, pp. 1-37) highlighted the fact that despite being the largest consumer region in the world, through oil indexed legacy contracts, Asian economies end up paying significantly more for their natural gas than they should. In-depth deliberations around the consequences of oil-index retention, particularly for Japan, can be found in Rogers and Stern (2014, pp. 1-65).

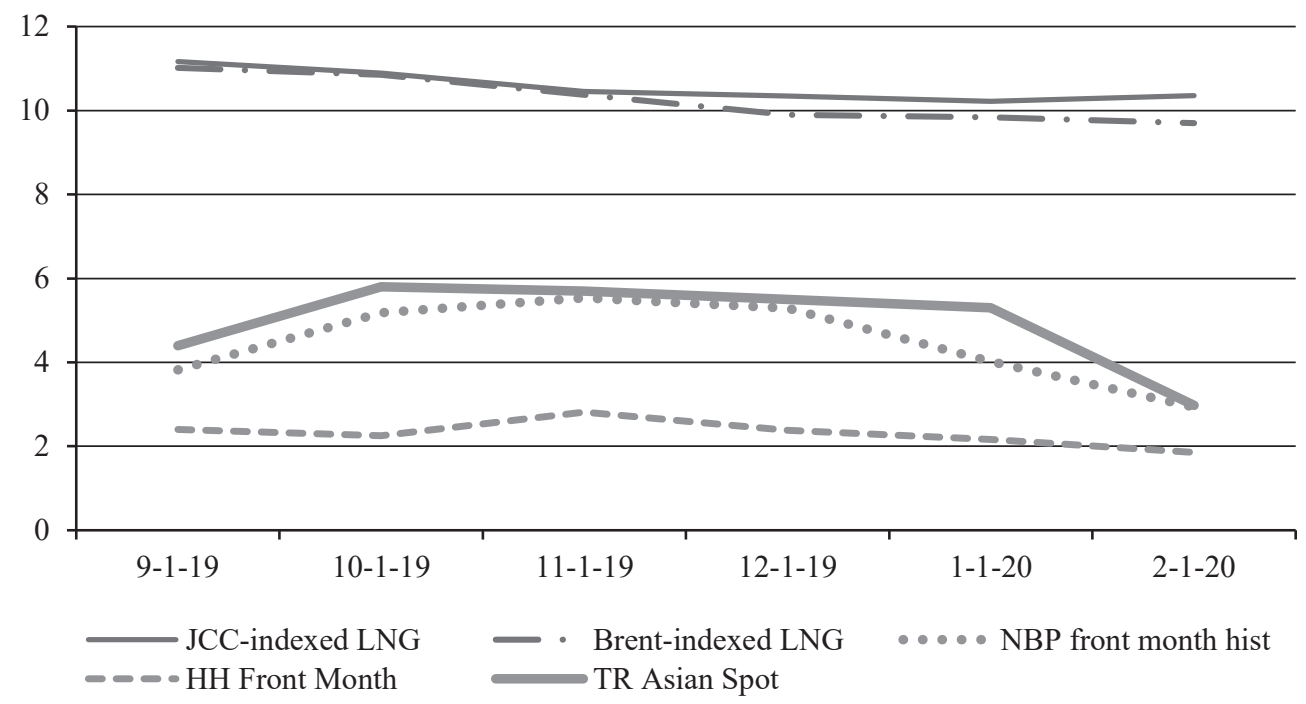

Fig. 2. Natural gas prices at the time of LNG oversupply [USD/MMBtu]

Source: own work based on (Thomson Reuters Eikon, 2019).

While analysing the spreads depicted in Figure 3, it is important to remember that not all transactions are conducted under long-term, oil-indexed arrangements (as already highlighted in Figure 2). Spot transactions are often referenced to the liquid prices observed in other regions. More recently, price reporting agencies have started publishing indices based on voluntarily reported transactions from the region (such as Platt's Japan Korea Marker (JKM)) (Patten and Thomson, 2017). These indices provide a better reference for short-term trends and can indicate that the spreads to Europe can be marginal at times (as shown in Figure 3 when looking at the level of Thomson Reuters's Asian spot index). Considering that the legacy arrangements constitute a larger share of the market in Asia than in the liberalized gas sectors in the USA and the EU, such price convergence is an extraordinary case resulting from LNG oversupply, whereas under different circumstances, consumer markets tended to compete over the cargoes (Fulwood, 2019, pp. 4-7). 
One important factor for competition over LNG, particularly between the two large consumer markets for gas, i.e. the EU and Asia (particularly Japan, China, Taiwan and Korea), are the transport costs. These can be decomposed into the following components (Timera Energy, 2018):

- chartering fee;

- fuel costs;

- port costs;

- canal costs;

- insurance costs.

The first component relates to the rental cost of a vessel, provided that a trader does not own it - the lease contracts can either cover a certain period of time, or relate to a single transport. Apart from the contract type, the chartering fee also depends on the vessel type, particularly its transport capacity. Fuel cost is the second largest transport-related cost, which naturally depends heavily on the distance, can be observed in Figures 4, 5 and 6 below. This cost also depends on the fuel used in a vessel's engine - typically heavy fuel oil in combination with the evaporated portion of the transported liquified fuel (the so-called boil-off) that appears in the tanks as a consequence of imperfect insulation from the external weather conditions (Dobrota, Lalić, and Komar, 2013, pp. 91-100). Port costs relate to the tariff paid for regasification services at LNG terminals, while the canal costs are borne while using the cross-continental routes (Osel, 2019).

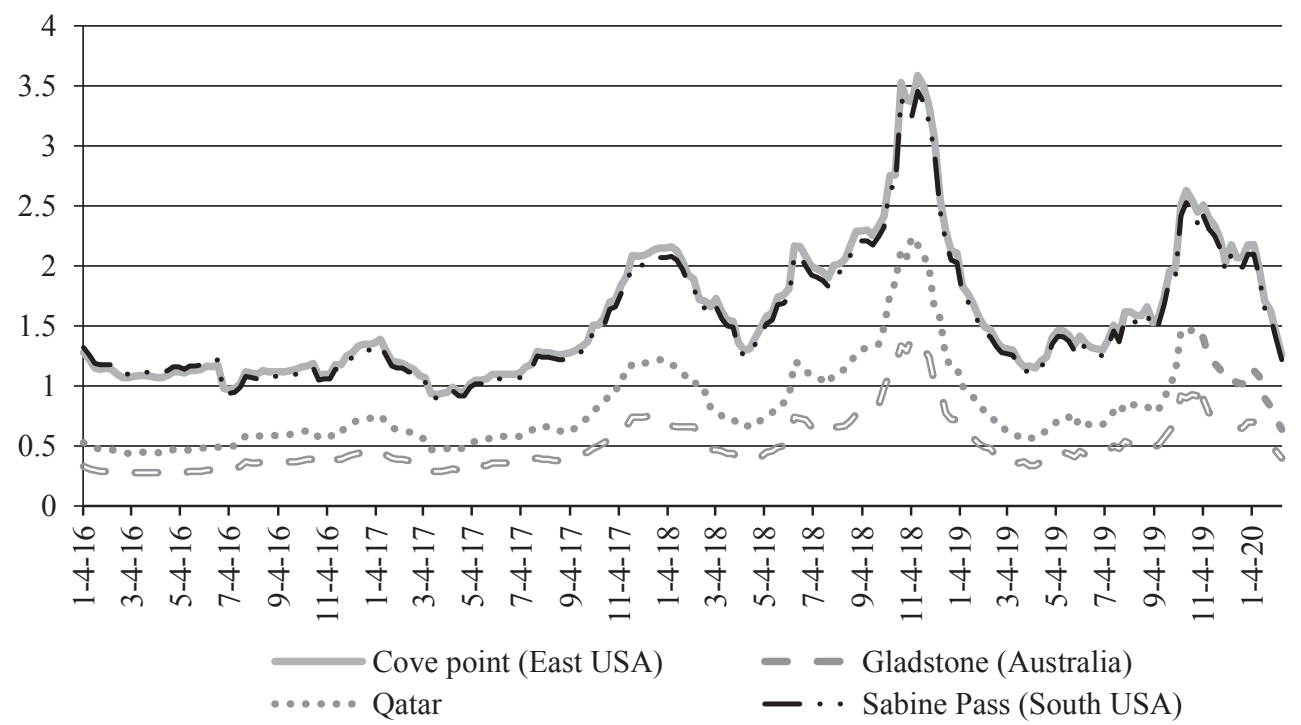

Fig. 3. Delivery costs to Japan [USD/MMBtu]

Source: own work based on (Thomson Reuters Eikon, 2019). 


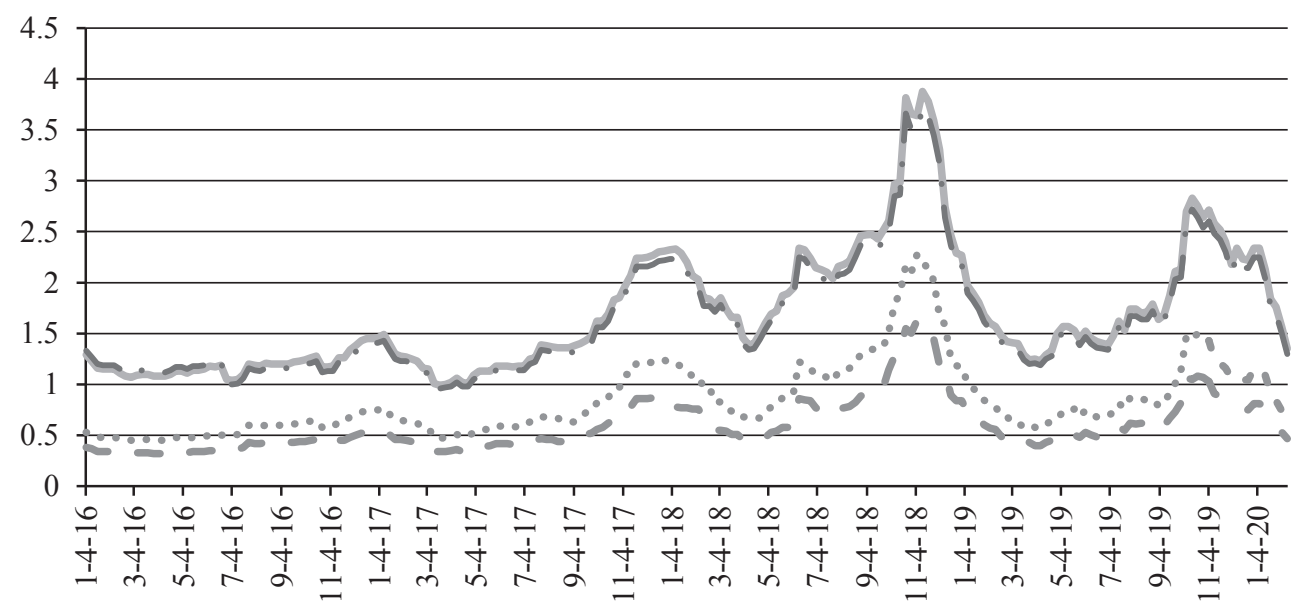

$$
\begin{array}{ll} 
& \text { Cove point (East USA) } \quad-\quad \text { Gladstone (Australia) } \\
\ldots . \text { Qatar } & \quad \text { Sabine Pass (South USA) }
\end{array}
$$

Fig. 4. Delivery costs to China [USD/MMBtu]

Source: own work based on (Thomson Reuters Eikon, 2019).

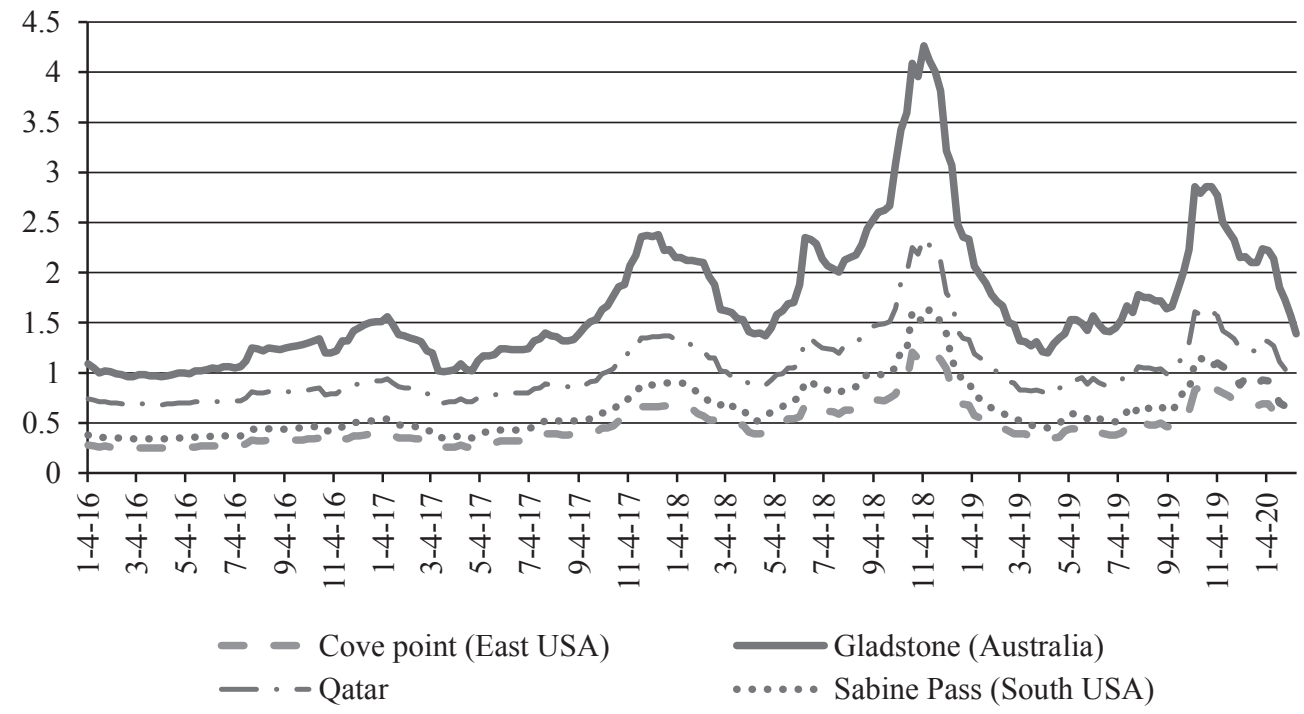

Fig. 5. Delivery costs to Spain [USD/MMBtu]

Source: own work based on (Thomson Reuters Eikon, 2019).

The analysis of the figures representing the delivery cost differences between different parts of the world indicates an apparent correlation between the transport costs from the major exporters. This can be explained both by the availability of the 
vessels that is limited and bound to increase along with the global demand for their services and the fuel costs (Rogers, 2018, pp. 7-9). The figures also confirm that the proximity of the delivery market automatically makes it the preferred destination for deliveries, since lower spreads are required to make the shipment economically viable. The additional advantage is the time to delivery, where the uncertainty over the price variations is far less significant in the short-term. It should also be noted that time to delivery is also important for the quality of the commodity itself - LNG suffers from the so-called ageing - a process during which the share of heavy components in the tank increases over time (Benito, 2009).

One notable point stemming from the presented graphs is the transport cost difference between the furthest and nearest exporting facility (i.e. between Cove Point and Gladstone) in the analysed period (January 2016 - February 2020):

- for Japan the maximum difference exceeded 2.23 USD/MMBtu, the minimum was at $0.64 \mathrm{USD} / \mathrm{MMBtu}$, averaging at around $1.07 \mathrm{USD} / \mathrm{MMBtu}$;

- for China the maximum and minimum transport costs were at $2.3 \mathrm{USD} / \mathrm{MMBtu}$ and 0.65 USD/MMBtu respectively (1.09 USD/MMBtu on average);

- the spread for Spain was moving between 0.71 USD/MMBu and as high as $3.125 \mathrm{USD} / \mathrm{MMBtu}$, averaging at around 1.22 USD/MMBtu.

These cost variations, although significant at times, do not rule out competition between cargoes even at longest distances, especially when considering the potential arbitrage against the legacy oil indexed contracts (as indicated in Figure 3). This proves that the global character of the gas market does not emerge as an outcome of temporary shifts in demand or the existence of soon-to-expire oil-indexed legacy contracts, but is a structural change that international trading companies adjust their strategies to.

\section{Implications for Europe}

When considering that typically the prices of natural gas are higher in Asia than in Europe and that destination clauses are forbidden under FOB contracts, under which cargoes can be diverted to higher price zones, the competitive position of the EU as the destination for LNG does not look very promising. Shipments from the USA can be attracted more easily distance-wise, yet the deliveries from Qatar, being by far the largest liquified gas exporter, can be far more vulnerable to the short-term price spreads. In order to understand the implications of this situation it is important to understand why Europe, being well connected with the nearest producers via a pipeline transmission system, should be interested in LNG shipments in the first place.

The author believes that there are three main reasons why LNG is an attractive gas source for the European Union. The first and most frequently quoted reason is the geopolitical significance of ensuring alternative supply sources to countries previously reliant on a single exporter. The second stems from the flexibility that LNG can provide to the gas network. The third argument relates to the fact that along 
with the development of liquefaction and regasification facilities around the world, liquified natural gas has reached a stage at which it can compete with pipeline gas, potentially bringing down the costs to end-customers.

The establishment of LNG regasification terminals has ended, or significantly reduced, the reliance of different EU countries on a single supply source, e.g. for Poland and Lithuania. Even when LNG remained significantly more expensive than pipeline gas, the sole fact that a country could rely on another delivery route in the event of a dispute with a supplier, put it in a much more favourable negotiation position. The positive effects of such diversification of gas sources go beyond the energy industry, since evidence of using gas supplies as a means of exerting political pressures can be found (Gringas, 2017).

The flexibility that LNG can provide to the system is important from the security of supply perspective. The demand for natural gas in Europe is weather dependent, both because of the extensive use of gas for heating purposes and because of gas being a popular backup fuel for power generation at times of low output from wind turbines and/or photovoltaics. Sudden shifts in demand can be covered by some flexibility readily available in the high-pressure transmission network (the so-called linepack) and through withdrawals from underground storage facilities (Qadrdan, Abeysekera, Wu, Jenkins, and Winter, 2020). Linepack availability is rather limited and can cater for relatively minor shifts in demand in the short-term, whereas storage can cover larger, often seasonal variations. LNG provides a third flexibility option, both through the availability of spot trading and bringing in cargoes in the short term to cover the additional demand and thanks to the short-term storage capacity inherent to the technology applied at regasification terminals (Lai, Wang, Kerke, and Scheller-Wolf, 2011, pp. 602-616). It therefore constitutes an attractive alternative, particularly to underground storage facilities, the services of which are often inflexible and expensive.

Finally, in the broader context, the emergence of LNG suppliers has greatly diversified the supply sources for the EU gas market. Growing global market for liquified gas has gradually reduced the technology and transportation-related costs to a level at which they can match the price level offered by pipeline gas suppliers (Steuer, 2019). The competition that this shift has brought about has impacted the prices tremendously and allowed the European hubs to grow in additional liquidity (European Commission, 2019, pp. 24-26). The global character of the gas market supports the development of liquidity on the most competitive European markets and helps them serve their purpose of keeping the end-customer prices as low as possible. This, in turn, has a positive impact on the competitive position of the EU economies (Trinomics, European Commission, 2018, pp. 153-174).

\section{Conclusion}

The transition towards market-based competition in the natural gas sector has proved to be a step in the right direction in the USA and many countries in Europe, marking an important change in the way the commodity was perceived internationally. This 
transition has empowered the importing countries, resulting not only in the greater flexibility of the contractual arrangements and lower prices for end-customers, but also in mitigating the potential of using gas supplies as a tool for exerting political pressure on the buyer.

Increasingly, short-term trade arrangements have raised the demand for flexibility services, which can be seen as a major advantage of liquified natural gas. This, in combination with the still existing long-term legacy contracts that create lucrative trading opportunities between the importing regions, has resulted in major investment in LNG infrastructure worldwide that, in turn, has expanded the volumes of commodity traded via ships. In an increasingly competitive environment, trading companies had the opportunity to delete the contractual provisions that limited their freedom to resale or divert the cargoes between the regions.

Statistics on the LNG delivery costs between different producers and importers prove that trades between the most distant counterparties can be concluded relatively frequently without the need for any exceptionally high spreads to emerge. This proves that the transition towards a global market for natural gas will continue to increase price convergence between the regions, and the growing competition will help optimizing the prices offered to end-customers.

In the new global context of a natural gas market, the European Union Member States are exposed both to opportunities and threats. The growing availability of LNG cargoes offered by the producers positively impacts the prices on the EU trading hubs. Multiple cargoes available in the short term provide additional flexibility to cover the swings in demand that can result from the changing weather conditions. On the other hand, if the prices in Europe remain at levels substantially lower than in Asia, the attractiveness of the EU hubs as a cargo destination will fall along with the surplus in supply. This would mean that some regions would either have to return to reliance on a single supply source or pay a premium for LNG supplies. Under less severe scenarios where countries could still rely on several pipeline gas supply routes, they would have to bear the costs of underutilized or stranded LNG infrastructure that would increase the prices for end-customers.

\section{References}

Agency for Cooperation of Energy Regulators. (2019). ACER Market Monitoring Report 2018 - gas wholesale market volume. Ljubljana: ACER.

Benito, A. (2009). Accurate determination of LNG quality unloaded in Receiving Terminals: An Innovative approach. Retrieved from http://www.iapg.org.ar/WGC09/admin/archivosNew/Special\%20 Projects/4.\%20IGU\%20Best\%20Practices/4.\%20IGU\%20Best $\% 20$ Practices\%20FINAL\%20-\%20CD $\% 20$ contents/8.\%20LNG\%20-\%20Accurate $\% 20$ determination $\% 20$ of $\% 20$ LNG $\% 20$ quality $\% 20$ unloaded $\% 20 \mathrm{in} \% 20$ receiving\%20terminals.pdf

Chong, Z. X. (2019). Changing Asian gas markets. Retrieved from https://www.doi.gov/sites/doi.gov/ files/migrated/intl/itap/upload/Session-01-01-Changing-Asian-gas-markets-Presentation.pdf 
Directive 98/30/EC of the European Parliament and of the Council of 22 June 1998 concerning common rules for the internal market in natural gas (Official Journal L 204, 21/07/1998).

Dobrota, D., Lalić, B., and Komar, I. (2013). Problem of boil - off in LNG supply chain. Transactions on Maritimes Science, (02), 91-100.

Energy Information Administration. (2017). Perspective on the development of LNG market hubs in the Asia Pacific region. Retrieved from https://www.eia.gov

European Commission. (2019). Quarterly report on European gas markets. Brussels: European Commission.

European Federation of Energy Traders. (2019). European gas hub study. Retrieved from https://efet. org/

Fulwood, M. (2019). LNG supply/demand balances, 2018-20205: Is there a problem? Oxford Energy Forum, (119), 4-7.

Gringas, A. (2017). The new geopolitics of natural gas. London: Harvard University Press.

Hartley, P. (2015). The Future of Long-term LNG Contracts. The Energy Journal, 36(2).

Herberg, M. (2011). Natural gas in Asia: history and prospects. Jakarta: Pacific Energy Summit. Retrieved from https://www.australiachinarelations.org

Hulshof, D., van der Maat, J. P., and Mulder, M. (2016). Market fundamentals, competition and naturalgas prices. Energy Policy, 94, 480-491.

International Group of Liquefied Natural Gas Importers. (2019a). LNG Markets \& Trade. LNG Trade. Retrieved from https://giignl.org

International Group of Liquefied Natural Gas Importers. (2019b). The LNG industry. GIIGNL Annual Report 2019. Retrieved from https://giignl.org/

Janusz, P., Kaliski, M., and Szurlej, A. (2015). The 'shale gas revolution' and changes on the LNG market. Gospodarka Surowcami Mineralnymi, 31(3), 5-24.

Juris, A. (1998). Development of competitive natural gas markets in the United States. Washington DC: The World Bank.

Lai, G., Wang, M. X., Kerke, S., and Scheller-Wolf, A. (2011). Valuation of storage at a liquefied natural gas terminal. Operations Research, 59(3), 602-616.

Melling, A. J. (2010). Natural gas pricing and its future. Europe as the battleground. Washington DC: Carnegie Endowment for International Peace.

Nalley, S. (2019). U.S. natural gas outlook. Retrieved from https://www.eia.gov

Neumann, A., and von Hirschausen, C. (2004). Less long-term gas to Europe? A quantitative analysis of European long-term gas supply contracts. Zeitschrift für Energiewirtschaft, 28(3), 175-182.

Osel, H. A. (2019). Natural gas: economics and environment. Australia: Aurora House.

Patten, A., and Thomson, P. (2017). LNG trading. In P. Griffin (ed.) Liquefied natural gas: the law and business of $L N G$. Surrey: Globe Law and Business Ltd.

Posner, R. A. (1968). Natural Monopoly and its Regulation. 21 Stanford Law Review, 548-643.

Price, C. W., and Bennett, M. (1999). New gas in old pipes: opening the UK residential gas market to competition. Utilities Policy, (8), 1-15.

Qadrdan, M., Abeysekera, M., Wu, J., Jenkins, N., and Winter, B. (2020). The Future of Gas Networks. The Role of Gas Networks in a Low Carbon Energy System. Switzerland: Springer.

Rogers, H. (2018). The LNG Shipping Forecast: costs rebounding, outlook uncertain. Oxford Energy Insight, (27), 1-18.

Rogers, H. V., and Stern, J. (2014). Challenges to JCC pricing in Asian LNG Markets. Oxford: Oxford Institute for Energy Studies.

Scherer, M. (ed.). (2018). International arbitration in the energy sector. Oxford: Oxford University Press.

Shi, X., and Variam, H. M. P. (2016). Gas and LNG trading hubs, hub indexation and destination flexibility in East Asia. Energy Policy, (96), 587-596. 
Stern, J., and Rogers, H. V. (2011). The transition to hub-base gas pricing in continental Europe. Oxford: Oxford Institute for Energy Studies.

Steuer, C. (2019). Outlook for competitive LNG supply. Oxford: Oxford Institute for Energy Studies.

Talus, K. (2018). Model diversion clause for LNG sale and purchase contracts. Retrieved from https:// www.jurists.co.jp

Thomas, S. (2003). Gas as Commodity. The UK gas market: from nationalism to the embrace of the free market. National Reforms in European Gas, 181-211.

Thomson Reuters Eikon. (2019). Database. Retrieved from https://eikon.thomsonreuters.com

Timera Energy. (2018). Deconstructing LNG shipping costs. Retrieved from https://timera-energy.com Trinomics, European Commission. (2018). Study on energy prices, costs and subsidiaries and their impact on industry and households. Final report. Retrieved from https://ec.europa.eu

Xunpeng, S. (2017). Gas and LNG pricing and trading hub in East Asia: An introduction. Natural Gas Industry $B,(3), 352-356$.

Zhang, D., Shi, M., and Shi, X. (2018). Oil indexation, market fundamentals, and natural gas prices: An investigation of the Asian premium in natural gas trade. Energy Economics, (69), 33-41.

\section{KONKURENCJA NA RYNKU LNG - KONSEKWENCJE DLA UNII EUROPEJSKIEJ}

Streszczenie: Celem niniejszego artykułu jest ocena wpływu ewolucji sektora gazu ziemnego w kierunku globalnego rynku towarowego na gospodarki Unii Europejskiej. Literatura przedmiotu dostarcza przykładów zmian w środowisku regulacyjnym i biznesowym oraz zmian technologicznych, które przyczyniły się do rozwoju globalnego rynku gazu ziemnego. Przeprowadzono analizę danych statystycznych w zakresie cen gazu ziemnego w różnych regionach świata oraz w zakresie różnic w kosztach dostaw LNG celem weryfikacji, czy globalny charakter handlu gazem ziemnym nie jest zjawiskiem tymczasowym. Wyniki potwierdzają, że rynkowe indeksy cenowe stały się bardziej przydatnym wyznacznikiem wartości gazu ziemnego w krótko- i długoterminowych umowach dostaw LNG niż indeksowanie względem cen ropy naftowej. Autor dowodzi, że rozwój globalnego rynku gazu ziemnego przyniósł wiele korzyści gospodarkom UE, które mogą zostać utracone, jeżeli gospodarki azjatyckie będą gotowe płacić więcej za dostawy LNG w przyszłości.

Słowa kluczowe: LNG, konkurencja, indeksowanie, rynek gazu. 